TUGAS 1 - 88675543

\title{
AUDIT LAPORAN KEUANGAN DAN TANGGUNG JAWAB AUDITOR
}

\section{Adit kusnandar}

\section{9}

Fakultas Komputer

$\underline{\text { Aditkusnanadar.student @umitra.ac.id }}$

\begin{abstract}
Audit Keuangan atau lebih tepat disebut sebagai Audit laporan keuangan merupakan penilaian atas suatu perusahaan atau badan hukum lainnya (termasuk pemerintah) sehingga dapat dihasilkan pendapat yang independen tentang laporan keuangan yang relevan, akurat, lengkap, dan disajikan secara wajar. Audit keuangan biasanya dilakukan oleh firmafirma akuntan karena pengetahuannya akan laporan keuangan
\end{abstract}

\section{A. PENDAHULUAN}


Audit laporan keuangan adalah penilaian atas suatu perusahaan atau badan hukum lainnya (termasuk pemerintah) sehingga dapat dihasilkan pendapat yang independen tentang laporan keuangan yang relevan, akurat, lengkap dan disajikan secara wajar. Hasil audit laporan keuangan harus memiliki manfaat baik bagi pihak internal maupun eksternal perusahaan. Selain itu, laporan audit memiliki keterbatasantertentu dan beberapa penyimpangan dari standar laporan audit, dan auditor harus mengetahui semuanya.masyarakat yang semakin kompleks menyebabkan pengguna laporan keuangan (pengambil keputusan ekonomi) dihadapkan kepada informasi yang semakin tidak bisa dipercaya. Agar dapat digunakan untuk berbagai kepentingan yang berbeda (yang sebagian di antaranya merupakan pihak diluar manajemen), maka laporan keuangan harus disusun berdasarkan kerangka laporan !euangan yang berlaku. cara pengguna laporan keuangan kadangkadang meragukan kewajaran informasi yang tertuang dalam

\section{B. PEMBAHASAN}

Audit Laporan Keuangan dan Tanggung Jawab Auditor

\section{Laporan Auditor Bentuk Baku}

Laporan audit bentuk baku (standar unqualified audit report) adalah laporan yang diterbitkan oleh seorang auditor ketika seluruh kondisi audit terpenuhi, tidak ditemukan kesalahan dalam penyajian yang signifikan yang tidak diperbaiki, laporan ini juga berisi pendapat auditor bahwa laporan keuangan telah disajikan secara wajar sesuai dengan GAAP/PSAK.
Fakultas Komputer

\section{TUGAS 1 - 88675543}

laporan keuangan yang disusun manajemen karna berbagai hal.\&ari uraian di atas, maka penulis tertarik untuk membuat makalah tentang Audit laporan keuangan agar nantinya mahasiswa yang telah

\section{Adit Kusnandar}

memperlajari mata kuliah audit setidaknya dapat memahami dan menyatakan pendapat atas kewajaran laporan keuangan, dalam semua hal yang material, sesuai dengan prinsipprinsip akuntansi yang berlaku umum.

Adapun unsur-unsur laporan auditor bentuk baku:

\section{Laporan}

Standar auditing telah menetapkan bahwa laporan audit harus harus diberi judul yang mengandung kata independen. Kata independen dicantumkan sebagai kewajiban, dengan tujuan untuk memberi tahu pemakai laporan bahwa audit tersebut dalam segala 
aspek dilaksanakan secara tidak memihak. Sebagai contoh judul yang tepat "Laporan Auditor Independen"

1. Alamat laporan audit

Laporan ini biasanya ditujukan kepada perusahaan, para pemegang saham, atau dewan direksi perusahaan.

\section{Paragraf pendahuluan}

Paragraf pendahuluan ini terbagi menjadi tiga hal. Pertama, laporan membuat suatu pernyataan yang sederhana bahwa kantor akuntan publik bersangkutan telah melaksanakan pengauditan. Pernyataan ini dibuat untuk membedakan laporan audit dari laporan kompilasi atau laporan riview.

Kedua, paragraf ini berupa laporan keuangan yang telah diaudit, termasuk tanggal neraca serta periode akuntansi untuk laporan laba rugi dan laporan arus kas.

Ketiga, laporan keuangan merupakan tanggung jawab manajemen, dan titanggung jawab auditor adalah menyatakan pendapat atas laporan yang telah diauditnya.

\section{Paragraf ruang lingkup}

Berisi pernyataan faktual tentang apa yang dilakukan auditor dalam proses pengauditan. Paragraf ruang lingkup menyatakan bahwa audit dirancang untuk memperoleh keyakinan penuh bahwa laporan keuangan telah bebas dari salah saji yang material.

Paragraf ruang lingkup juga membahas bukti audit yang dikumpulkan telah sesuai dengan pernyataan yang disampaiakan.
1. Paragraf pendapat

Paragraf terakhir dalam laporan audit berisi kesimpulan auditor berdasarkan hasil audit.

\section{Nama KAP (Kantor Akuntan Publik)}

Fakultas Komputer

\section{TUGAS 1 - 88675543}

Nama sebagai identitas kantor akuntan publik (KAP) atau praktisi yang melaksanakan audit, biasanya yang dituliskan adalah nama kantor akuntan publik.

\section{Tanggal laporan audit}

Tanggal yang tepat untuk dicantumkan pada laporan audit adalah ketika auditor menyelesaikan prosedur audit di lokasi pemeriksaan.

\section{Opini Auditor}

Jenis-jenis opini auditor yang diberikan kepada klien terbagi menjadi lima bagian.

1. Opini wajar dengan pengecualian (unqualified opinion)

Adalah pen dapat yang diberikan ketika audit telah dilaksanakan sesuai standar auditing (SPAP), auditor tidak menemukan kesalahan material secara keseluruhan laporan keuangan atau tidak ada penyimpangan dari prinsip akuntansi yang berlaku (SAK). 
Bentuk laporan ini digunakan apabila dalam keadaan:

1. Bukti audit yang dibutuhkan telah terkumpul secara mencukupi dan auditor telah menjalankan tugasnya sedemikian rupa, sehingga ia dapaty memastikan kerja lapangan telah ditaati.

2. Ketiga standar umum telah diikuti sepenuhnya dalam perikatan kerja.

3.keuangan yang di audit disajikan sesuai dengan prinsip akuntansi yang berlaku di Indonesia dan konsisten pada laporan-laporan sebelumnya. Tidak ada ketidakpastian yang berarti (no material uncertainties) mengenai perkembangan di masa mendatang yang tidak dapat diperkirakan sebelumnya atau dipecahkan dengan memuaskan.

\section{Adit Kusnandar}

4.Opini wajar tanpa pengecualian dengan paragraf penjelas (Modified Unqualified Opinion)

Pendapat ini diberikan ketika suatu keadaan tertentu tidak berpengaruh langsung terhadap

opini wajar. Keadaan ini terjadi apabila:

1. Pendapat auditor sebagian didasarkan atas pendapat auditor independen lain.
2. Karena belum ada aturan yang jelas, maka lap. keuanagan dibuat menyimpang dari SAK.

3. Laporan dipengaruhi ketidakpastian peristiwa yang akan datang dan hasilnya belum bisa diperkirakan pada tanggal lap. audit.

4. Ada keraguan dalam kemampuan satuan usaha.

5. Diantara dua periode akuntansi terdapat perubahan yang material dalam penerapan prinsip akuntansi.

6. Data keuangan tertentu yang diharuskan ada oleh BAPEPAM namun tidak disajikan.

7. Opini wajar dengan pengecualaian (Qualified Opinion)

Dalam hal ini opini diberikan ketika lap.keuangan dikatakan wajar dalam hal materi, tapi ada penyimpangan/kurang lengkap pada pos tertentu, sehingga harus dikecualikan. Pengecualian terjadi jika:

1. Bukti kurang cukup

2. Ada pembatasan ruang lingkup

3. Ada penyimpangan penerapan prinsip akuntansi (SAK)

4. Opini tidak wajar (Adverse Opinion)

Fakultas Komputer

TUGAS 1 - 88675543

Opini yang diberikan ketika secara keseluruhan auditor harus memberi tambahan paragraf untuk 
menjelaskan ketidakwajaran atas laporan keuangan, disertai dengan dampak dari akibat ketidakwajaran tersebut, pada laporan auditnya.

1. Opini Tidak Memberikan Pendapat (Disclaimer of opinion)

Adalah pendapat yang diberikan ketika ruang lingkup pemeriksaan yang dibatasi, sehingga auditor tidak melaksanakan pemeriksaan sesuai dengan standar auditing yang ditetapkan IAI. Pembuatan laporannya auditor harus memberi penjelasan tentang pembatasan ruang lingkup oleh klien yang mengakibatkan auditor tidak memberi pendapat.

Tahap-tahap Opini Audit

Sebelum auditor memberikan pendapat (opininya), seseorang auditor harus melaksanakan tahaptahap audit. Adapun tahap-tahapnya menurut Arens etal (2008:132) yaitu sebagai berikut:

1. Perencanaan dan pendekatan audit

2. Pengujian pengendalian dan transaksi

3. Pelaksanaan prosedur analitis dan pengujian terinci atas saldo

4. Penyelesaian dan penerbitan laporan audit.

\section{KESIMPULAN}

Kesimpulan yang bisa dinyatakan, tindakan kedua belah pihak yakni auditor BPKmaupun KPU kurangetis. Tidak etis seorang auditor melakukan komunikasi kepada pihakyang diperiksa atau pihak penerima kerja (KPU)dengan mendasarkan pada imbalan sejumlahuang sebagaimana terjadi pada kasus Mulyana W Kusumah,

\section{Adit Kusnandar}

Sekalipun kita tahu bahwa itudilakukan demi alasan tujuan mulya yaitu pengungkapan korupsi di KPU. Pengungkapankorupsi harus dilakukan dengan cara-cara, teknik, dan prosedur profesi yang menjaga,menjunjung, menjalankan dan mendasarkan pada etika profesi. Dari sudut pandang etikaprofesi, auditor tampak tidak bertanggungjawab.

\section{DISKUSI}

Kesimpulan yang bisa dinyatakan, tindakan kedua belah pihak yakni auditor BPKmaupun KPU kurangetis. Tidak etis seorang auditor melakukan komunikasi kepada pihakyang diperiksa atau pihak penerima kerja (KPU)dengan mendasarkan pada imbalan sejumlahuang sebagaimana terjadi pada kasus Mulyana W Kusumah, Sekalipun kita tahu bahwa itudilakukan demi alasan tujuan mulya yaitu pengungkapan korupsi di KPU. Pengungkapankorupsi harus dilakukan dengan cara-cara, teknik, dan prosedur profesi yang menjaga,menjunjung, menjalankan dan mendasarkan pada etika profesi. Dari sudut pandang etikaprofesi, auditor tampak tidak 
bertanggungjawab, yaitu dengan cara penggunaan jebakanimbalan uang untuk menjalankan profesinya.

Auditor juga tidak punya integritas

ketikadalam benaknya sudah ada

pemihakan pada salah satu

pihak, yaitu KPK

denganberkesimpulan bahwa telah

terjadi korupsi. Dari sisi

independensi, auditor BPK

yangbersangkutan sangat pantas

diragukan. Hal ini terlihat dadalam

teks di atas dimana bahkanketua BPK

tidak mengetahui kroologis peristiwa

sampai ia diberithui oleh wakil ketua

BPK.Kemudian tampak bahwa

Fakultas Komputer

TUGAS 1 - 88675543

auditor BPK tidak percaya pada

kemampuan

professionalakuntansinya. Dengan

teknik dan prosedur yang juga telah

diatur dalam profesi akuntan,pasti

akan terungkap hal-hal negatif,

termasuk dugaan korupsi kalau

memang terjadi. Alih-alih

menggunakan kemampuan

profesionalnya, auditor BPK

menggunakan cara-cara yangtidak

etis yaitu menjebak.

\section{E. REFERENCE}

https://dokumen.tips/documents/makalah -audit-keuangan.html

https://www.kompasiana.com/sutrihary/5 639b0bbcc9273810b914586/audit- 
